\title{
Characteristics of Pulmonary Tuberculosis Patients and Their Houses in Kedungwuni Subdistrict, Pekalongan Regency, Indonesia
}

\author{
Nuniek Nizmah Fajriyah ${ }^{1 *}$, Siti Khuzaiyah ${ }^{2}$, Nur Izzah ${ }^{1}$ \\ ${ }^{1}$ Department of Nursing, Universitas Muhammadiyah Pekajangan Pekalongan 51172, Indonesia \\ ${ }^{2}$ Department of Midwifery, Universitas Muhammadiyah Pekajangan Pekalongan 51172, Indonesia \\ *Corresponding author. Email: nuniek@umpp.ac.id
}

\begin{abstract}
Pulmonary tuberculosis (TB) is a health problem in terms of mortality, disease incidence, and its diagnosis and treatment. In 2015, there were 175,029 positive cases of pulmonary TB. Pulmonary TB is more prevalent in males with a prevalence of $106,554(60.9 \%)$ than females with prevalence of $68,475(39.1 \%)$. Based on data from the Health Office of Pekalongan Regency in 2016, Pekalongan had 610 patients with pulmonary tuberculosis suspects consisting of men as many as 338 and women as many as 272 . This study aimed to explore the characteristics of pulmonary tuberculosis patients and their house in Kedungwuni Subdistrict, Pekalongan Regency. This study was a descriptive quantitative study. The majority of respondents were 38 men $(62.3 \%)$, their age of 46-55 was 17 people $(27.9 \%)$, almost half of the respondents had elementary school education (27 people, 44.3\%), most respondents had low economic status (55 people, 90.2\%), almost half of the respondents were employee (27 people, $44.3 \%$ ), and the majority of respondents did not have the same TB in their family (42 people, $78.9 \%$ ). Most of the respondents $(57.4 \%$ ) had poor housing conditions. The results of this study are expected to be used to improve the quality of care in tuberculosis patients.
\end{abstract}

Keywords: pulmonary tuberculosis, health, Kedungwuni Subdistrict

\section{INTRODUCTION}

Tuberculosis (TB) remains one of the ten leading causes of death worldwide. Millions of people continue to get sick from TB every year. Pulmonary tuberculosis (TB) is a contagious lung infection that is still a health problem in the world, especially in developing countries. Tuberculosis has been declared by the WHO (World Health Organization) as a Global Emergency since 1992 [1]. Unfortunately, clinical trials to find out a vaccine that prevents transmission of infection has been disappointing. Significant problems include lack of biomarkers and understanding of the mechanisms of disease and protection [2].

WHO estimates that between 2002 and 2020, 1,000 million people will be infected, more than 150 million people will be sick, and 36 million will die of TB if control is not good in the future. Tuberculosis is the number one killer among infectious diseases and the 3rd leading cause of death after heart disease and acute respiratory disease in Indonesia. The death rate due to tuberculosis in Indonesia reaches 100 thousand people in a year plus 26 thousand people with tuberculosis who are HIV positive, while the world mortality rate caused by the bacterium mycobacterium tuberculosis has reached 1.4 million-plus 390 thousand people who are HIV positive. While the prevalence of TB patients in Indonesia in 2018 is 842 per 100 thousand population with a mortality rate of 107 thousand cases. This number makes Indonesia ranked as the third-highest for TB cases after India and China [1]. In Pekalongan Regency, pulmonary TB is one of the ten leading causes of death in Pekalongan [3].

Pulmonary tuberculosis is a health problem in terms of mortality, disease incidence, and diagnosis and treatment [1]. Tuberculosis (TB) is a chronic infectious disease caused by mycobacterium tuberculosis. This bacterium grows slowly in the body that contains a lot of blood vessels and oxygen. Therefore, TB often attacks the lungs.

In 2015 , there were 175,029 positive cases of pulmonary tuberculosis. Pulmonary TB by sex is more prevalent in males with a prevalence of $106,554(60.9 \%)$ than females with an incidence of 68,475 (39.1\%)[4]. Pulmonary tuberculosis, according to the provincial level was ranked highest, namely North Sulawesi with 206, Gorontalo with 129, and North Sumatra with 120 cases from 34 provinces. The Province of Central Java in 2015 was ranked as the $26^{\text {th }}$ out of 34 Provinces with 56 positive Mycobacterium tuberculosis cases [4]. Patients with positive of bacterium Mycobacterium tuberculosis in Central Java in 2015 amounted to 115.17 per 100,000 population. In the Health Office of Pekalongan Regency, in 2016, the number of patients with suspect of tuberculosis was 610 consisting of 338 men and 272 women from first to third quarter.

Tuberculosis is also related to social problems. The characteristics of tuberculosis patients are related to tuberculosis cases. There are several factors of tuberculosis: well-established risk factors (such as human immunodeficiency virus, malnutrition, and young age), emerging variables such as diabetes, indoor air pollution, alcohol, use of immunosuppressive drugs, and tobacco smoke, socioeconomic and behavioural factors [5]. On the 
other hand, the household condition and community sources will increase the risk of infection from birth until 20 years of age [6]. However, the data of the patient's houses, including floor, wall, density and other relating house conditions have not been reported yet. The objective of this study was to explore the characteristics of pulmonary tuberculosis patients and their house in Pekalongan Regency, Central Java, Indonesia.

\section{METHOD}

This research was a survey study. It was conducted on December 22 to January 7, 2019, in Kedungwuni Public Health Center I and Kedungwuni Public Health Center II in Pekalongan Regency with a total sample of 61 respondents. The data analysis was descriptive-analytic to determine the percentage of data.

Table 1 Characteristic of respondents

\begin{tabular}{|c|c|c|c|c|}
\hline No & Characteristic & $\mathbf{n}$ & f (\%) & $\mathbf{N}(\%)$ \\
\hline \multirow[t]{3}{*}{1} & Sex & & & \multirow[b]{3}{*}{$34(100)$} \\
\hline & Male & 38 & 62.3 & \\
\hline & Female & 23 & 37.7 & \\
\hline \multirow[t]{6}{*}{2} & Age & & & \multirow{6}{*}{$34(100)$} \\
\hline & Late adolescents & 14 & 23.0 & \\
\hline & Early old & 16 & 26.2 & \\
\hline & Late old & 9 & 14.8 & \\
\hline & Early elderly & 17 & 27.9 & \\
\hline & Late elderly & 5 & 8.2 & \\
\hline \multirow[t]{5}{*}{3} & Education level & & & \multirow{5}{*}{$34(100)$} \\
\hline & No school & 7 & 11.5 & \\
\hline & Elementary school & 27 & 44.3 & \\
\hline & Junior high school & 15 & 24.6 & \\
\hline & Senior high school & 12 & & \\
\hline \multirow[t]{3}{*}{4} & Economic status & & & \multirow{3}{*}{$34(100)$} \\
\hline & Low & 55 & 90.2 & \\
\hline & High & 6 & 9.8 & \\
\hline \multirow[t]{6}{*}{5} & Employment & & & \multirow{6}{*}{$34(100)$} \\
\hline & Unemployed & 26 & 42.6 & \\
\hline & Private/public employee & 2 & 3.3 & \\
\hline & Entrepreneur & 4 & 6.6 & \\
\hline & Labour & 27 & 44.3 & \\
\hline & Others & 2 & 3.3 & \\
\hline \multirow[t]{3}{*}{6} & Similar Tuberculosis & & & \\
\hline & Yes & 19 & 31.1 & \multirow{2}{*}{$34(100)$} \\
\hline & No & 42 & 68.9 & \\
\hline
\end{tabular}

\section{RESULTS AND DISCUSSION}

The majority of respondents were male $(62.3 \%)$. TB case notification rate is usually higher in men than in women. Moreover, in the low-and middle-income countries, TB prevalence is significantly higher among men than women[7]. Men should be considered a high-risk group for TB. The incidence of pulmonary TB more often affects men than women [14]. This is because men tend to like to consume cigarettes and alcoholic drinks so that it can decrease the immune system. So, it is natural that smokers and alcoholic drinkers are often referred to as agents of pulmonary TB. Another study showed that the most significant percentage of tuberculosis $(59 \%)$ was found in males compared to females $(41 \%)$ [8].

In terms of the age of respondents, most of the respondents have an early elderly category (46-55 years) which was 17 people $(27.9 \%)$. The previous study revealed that the incidence of TB has begun to shift to the older population. The proportion of older people increased from $10.5 \%$ to $12 \%$ and the medium age from 38 to 41 years between the period between 1986 and 1996. The medium age of death increased from 53 to 55 years between 1980 and 1996 . Higher mobility and social interaction in people aged 15-50 years, who have to work to earn income to meet family needs, allows them to be infected from other people to be higher [9].

Based on the results of the study, the data obtained most of the respondents who graduated from elementary school were 27 people $(44.3 \%)$. According to WHO states that pulmonary TB attacks people with low education. The level of education can influence behaviour. The higher the knowledge of a person, the easier it is to receive information. The study is likely to occur because before pulmonary TB patients undergo treatment, they lack information or knowledge about pulmonary $\mathrm{TB}$ disease. The main risk factor for TB was not having university-level education $(\mathrm{OR}=4.45 .95 \% \mathrm{CI}(1.50-13.17), \mathrm{p}=0.007)$ [10]. There was also a significant relationship between education to the dropout treatment of TB [8].On the other hand, low education, in turn, can lead to further poverty[10]

Based on the results of the study, some respondents (90.2\%) had a low economic status with income below the regional minimum wage. Adequate nutritional needs will guarantee a good immune status, and a healthy home environment will reduce the risk of developing $M$. tuberculosis germs, as well as protect people from transmitting germs. Meanwhile, health needs that cannot be met will delay the recovery 
and health maintenance. Based on the results of the study, the majority of respondents had jobs as labourers (44.3\%). Regarding the TB cases in the neighbourhood, the majority $(68.9 \%)$ of respondents did not have similar TB both from their families and neighbours. While 19 respondents $(31.1 \%)$ had the same TB from their family members and their neighbours. The risk of progression from exposure to the tuberculosis bacilli to the development of active disease is a two-stage process governed by both exogenous and endogenous risk factors [5].

Table 2 The profile of patients' home

\begin{tabular}{|c|c|c|c|c|}
\hline No & Characteristic & $\mathbf{n}$ & $\mathbf{f}(\%)$ & $\mathbf{N}(\%)$ \\
\hline 1 & House yard & & & \multirow{4}{*}{$34(100)$} \\
\hline & Available and clean & 14 & 23.0 & \\
\hline & Available and dirty & 17 & 27.9 & \\
\hline & Unavailable & 30 & 49.2 & \\
\hline \multirow[t]{3}{*}{2} & Each house position & & & \multirow{3}{*}{$34(100)$} \\
\hline & With space & 31 & 50.8 & \\
\hline & No space & 30 & 49.2 & \\
\hline \multirow[t]{4}{*}{3} & Road condition & & & \multirow{4}{*}{$34(100)$} \\
\hline & $>2 \mathrm{~m}$ & 7 & 11.5 & \\
\hline & $1.5-2 \mathrm{~m}$ & 27 & 44.3 & \\
\hline & $<1 \mathrm{~m}$ & 27 & 44.3 & \\
\hline \multirow[t]{3}{*}{4} & House density & & & \multirow{3}{*}{$34(100)$} \\
\hline & Good & 38 & 62.3 & \\
\hline & $\mathrm{Bad}$ & 23 & 37.7 & \\
\hline \multirow[t]{3}{*}{5} & Neighbourhood & & & \multirow{3}{*}{$34(100)$} \\
\hline & Good & 20 & 32.8 & \\
\hline & $\mathrm{Bad}$ & 41 & 67.2 & \\
\hline \multirow[t]{4}{*}{6} & House ceiling & & & \multirow{4}{*}{$34(100)$} \\
\hline & Available, clean, safe & 20 & 32.8 & \\
\hline & Available, dirty, difficult in caring, unsafe & 24 & 39.3 & \\
\hline & Unavailable & 17 & 27.9 & \\
\hline \multirow[t]{3}{*}{7} & Wall & & & \multirow{3}{*}{$34(100)$} \\
\hline & Permanent & 41 & 67.2 & \\
\hline & Semi-permanent/combination & 21 & 34.4 & \\
\hline \multirow[t]{4}{*}{8} & Floor & & & \multirow{4}{*}{$34(100)$} \\
\hline & Permanent/ceramics & 50 & 82.0 & \\
\hline & Semi-permanent & 9 & 14.8 & \\
\hline & Soil & 2 & 3.3 & \\
\hline \multirow[t]{3}{*}{9} & Windows in the bedrooms & & & \multirow{3}{*}{$34(100)$} \\
\hline & Available & 54 & 88.5 & \\
\hline & Unavailable & 7 & 11.5 & \\
\hline \multirow[t]{3}{*}{10} & Windows in the family rooms & & & \multirow{3}{*}{$34(100)$} \\
\hline & Available & 56 & 91.8 & \\
\hline & Unavailable & 5 & 8.2 & \\
\hline \multirow[t]{3}{*}{11} & Ventilation & & & \multirow{3}{*}{$34(100)$} \\
\hline & Available $(>10 \%)$ & 16 & 26.2 & \\
\hline & Available $(<10 \%)$ & 45 & 73.8 & \\
\hline \multirow[t]{4}{*}{12} & Kitchen smoke ventilation & & & \\
\hline & Available (>10\%) & 18 & 29.5 & \\
\hline & Available $(<10 \%)$ & 38 & 62.3 & $34(100)$ \\
\hline & Unavailable & 5 & 8.2 & \\
\hline 13 & Lighting & & & \\
\hline & Good enough & 24 & 39.3 & $34(100)$ \\
\hline & $\mathrm{Bad}$ & 37 & 60.7 & $34(100)$ \\
\hline 14 & Clean water facilities & & & \\
\hline & Available, public, bad & 2 & 3.3 & \\
\hline & Available, private, bad & 7 & 11.5 & $34(100)$ \\
\hline & Available, private, good & 48 & 78.7 & $34(100)$ \\
\hline & Available, public, good & 4 & 6.6 & \\
\hline
\end{tabular}




\begin{tabular}{|c|c|c|c|c|}
\hline No & Characteristic & $\mathbf{n}$ & f $(\%)$ & $\mathbf{N}(\%)$ \\
\hline 15 & Toilet facilities & & & \multirow{4}{*}{$34(100)$} \\
\hline & Available, bad & 10 & 16.4 & \\
\hline & Available, moderate & 39 & 63.9 & \\
\hline & Available, god & 12 & 19.7 & \\
\hline \multirow[t]{5}{*}{16} & water disposal facilities & & & \multirow{5}{*}{$34(100)$} \\
\hline & Unavailable & 3 & 4.9 & \\
\hline & Available, bad & 23 & 37.7 & \\
\hline & Available, moderate & 29 & 47.5 & \\
\hline & Available, good & 6 & 9.8 & \\
\hline \multirow[t]{4}{*}{17} & Waste disposal facilities & & & \multirow{4}{*}{$34(100)$} \\
\hline & Available, bad & 16 & 26.2 & \\
\hline & Available, moderate & 25 & 41.0 & \\
\hline & Available, god & 20 & 32.8 & \\
\hline \multirow[t]{7}{*}{18} & Daily habit & & & \multirow{4}{*}{$34(100)$} \\
\hline & Open bedroom windows regularly & 12 & 19.7 & \\
\hline & Sometimes & 42 & 68.9 & \\
\hline & Never & 7 & 11.5 & \\
\hline & Open family room windows regularly & 12 & 19.7 & \multirow{3}{*}{$34(100)$} \\
\hline & Sometimes & 42 & 68.9 & \\
\hline & Never & 7 & 11.5 & \\
\hline \multirow[t]{4}{*}{19} & Cleaning house & & & \multirow{4}{*}{$34(100)$} \\
\hline & Daily & 18 & 29.5 & \\
\hline & Sometimes & 42 & 68.9 & \\
\hline & Never & 1 & 1.6 & \\
\hline \multirow[t]{4}{*}{20} & Baby faeces & & & \multirow{4}{*}{$34(100)$} \\
\hline & River/pool/undefined & 1 & 1.6 & \\
\hline & sometimes waste bracket & 36 & 59.0 & \\
\hline & Waste bracket (daily) & 24 & 39.3 & \\
\hline \multirow[t]{3}{*}{21} & House condition & & & \multirow{3}{*}{$34(100)$} \\
\hline & Good & 26 & 42.6 & \\
\hline & Poor & 35 & 57.4 & \\
\hline
\end{tabular}

Based on the results of the study, most of the respondents $(57.4 \%)$ had poor housing conditions. Respondents who had good housing conditions were only 26 people $(42.6 \%)$. Most respondents have a window in the room and family room, but the window did not meet the minimum standard of ventilation that it should be a minimum $10 \%$ of the area of the room. The condition of the house of patients with pulmonary TB who have ventilation area that was not good $(<10 \%$ of the floor area) was 45 people $(73.4 \%)$. Area of ventilation that was inadequate for health would result in the function of ventilation to be not optimal. Therefore, the possibility that occurs was that the bacteria Micro bacterium tuberculosis could not be eliminated by expelling through ventilation into the house; this might increase the risk of infection in the room.

This study confirms the previous research on the characteristics of pulmonary TB sufferers in West Bandung Regency, which states that poor home conditions will affect the transmission of pulmonary TB such as poor ventilation area $(<10 \%)$ and lighting that is not optimal. So that $\mathrm{M}$. Tuberculosis germs will be difficult to get out and pollute the room [13]. Based on the Regulation of the Minister of Health of the Republic of Indonesia Number 1077 / MENKES / PER / V / 2011, several diseases such as pulmonary tuberculosis often occur in environments and places with poor indoor air quality. Low air change rates were typical to happen among TB patients, particularly in bedrooms, and overcrowding was also common [11]. Poor hygiene might lead to various environmental-based diseases [12].
"Narrated from Sa'ad bin Abi Waqas from his father, from Prophet Muhammad PBUH: Verily, Allah SWT is Holy who likes things that are pure, He is clean, who likes cleanliness, $\mathrm{He}$ is noble who likes glory, $\mathrm{He}$ is beautiful and loves beauty, therefore clean your places "(HR. Tirmizi). The condition of a dirty house, dirty, and a lot of garbage scattered about it is something that is not liked by Allah SWT. As obedient servants, of course, we must be compelled to do things that are liked by God one of which is the cleanliness of the house.

\section{CONCLUSION}

There were variances regarding the characteristics of the respondent and their houses. Specific approaches are needed for caring patients with TB disease.

\section{ACKNOWLEDGMENT}

Thank you conveyed to the Department of Research, Community Service, and Publication of The University of Muhammadiyah Pekajangan Pekalongan Indonesia for supporting this study. 
Meta-analysis," PLoS Med., vol. 13, no. 9, pp. 1-23, 2016.

[8] V. Da Silva, S. Tigeh, N. Wirawan, and M. Bakta, "The Relationship Between Education, Job, and Family Income with TB Medication Dropouts in Timor-Leste," Bali Med. J., vol. 5, no. 2, p. 97, 2016.

[9] F. Chaimowicz, "Age transition of tuberculosis incidence and mortality in Brazil.," Rev. Saude Publica, vol. 35, no. 1, pp. 81-87, 2001.

[10] A. Jiamsakul et al., "Socio-economic status and risk of tuberculosis: A case-control study of HIVinfected patients in Asia," Int. J. Tuberc. Lung Dis., vol. 22, no. 2, pp. 179-186, 2018.

[4] K. K. dan K. Ketenagakerjaan, "Panduan Pengendalian Tuberkulosis diTempat Kerja,” pp. 1-80, 2015.

[5] P. D. O. Davies, "Risk factors for tuberculosis," Monaldi Arch. Chest Dis. - Pulm. Ser., vol. 63, no. 1, pp. 37-46, 2005.

[6] J. L. Zelner et al., "Age-specific risks of tuberculosis infection from household and community exposures and opportunities for interventions in a highburden setting," Am. J. Epidemiol., vol. 180, no. 8, pp. 853-861, 2014.

[7] K. C. Horton, P. MacPherson, R. M. G. J. Houben, R. G. White, and E. L. Corbett, "Sex Differences in Tuberculosis Burden and Notifications in Low- and Middle-Income Countries: A Systematic Review and
[11] F. A. Khan et al., "Housing characteristics as determinants of tuberculosis in an Inuit community: a case-control study," 2015.

[12] P. Tuberculosis, "Analisis Mycobacterium Tuberculosis Dan Kondisi Fisik," no. February, pp. 152-162, 2017.

[13] Hartono, A.Y. 'Karakteristik Penderita Tuberkulosis Paru dan Lingkungan Rumah di Wilayah Kerja Puskesmas Padalarang Kabupaten Bandung Barat Periode Mei-Juli 2012'. Skripsi. Fakultas Kedokteran. Universitas Islam Bandung. 2012.

[14] Naga, S.S. Buku Panduan Lengkap Ilmu Penyakit Dalam. Yogjakarta: Diva Press. 2014. 